NASA Technical Memorandum 107366

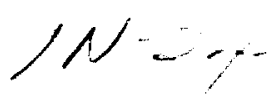

$01=2,2$

\title{
Thermomechanical Behavior of Advanced SiC Fiber Multifilament Tows
}

Hee Mann Yun and James A. DiCarlo

Lewis Research Center

Cleveland, Ohio

Prepared for the

20th Annual Conference on Composites, Advanced Ceramics, Materials, and Structures

sponsored by the American Ceramic Society

Cocoa Beach, Florida, January 7-11, 1996

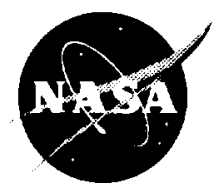

National Aeronautics and

Space Administration 
Trade names or manufacturers' names are used in this report for identification only. This usage does not constitute an official endorsement, either expressed or implied, by the National Aeronautics and Space Administration. 


\title{
THERMOMECHANICAL BEHAVIOR OF ADVANCED SIC FIBER MULTIFILAMENT TOWS
}

\author{
Hee Mann Yun and James A. DiCarlo \\ NASA Lewis Research Center \\ Cleveland, Ohio
}

\begin{abstract}
$\underline{\text { Abstract }}$
In order to relate single fiber behavior to multiple fiber behavior in composites, fast-fracture tensile strength, creep, and stress-rupture studies were conducted on advanced $\mathrm{SiC}$ fiber multifilament tows in the temperature range from 20 to $1400 \mathrm{C}$ in air as well as in inert environments. For conditions of small fiber creep (short times and low temperatures), the tow results of this study confirm the ability of limited single fiber data to model the strength behavior of multiple fibers in a bundle. For conditions of high creep (long times and high temperatures), further studies are needed to explain tow rupture behavior being better than average single fiber behavior.

\section{Introduction}

Substantial interest in continuous silicon carbide fibers has developed because of their potential reinforcement of ceramic matrix composites (CMC) for high temperature structural components. Currently, small diameter SiC fibers derived by polymer pyrolysis possess high stiffness, high room temperature strength, and high thermal stability. The Dow Corning fiber (nearly stoichiometric beta- SiC) and the Hi-Nicalon fiber (beta-SiC with excess carbon and trace oxygen) are leading candidates for high temperature CMC because they have been observed to display creep and rupture behavior superior to that of the high-oxygen containing Nicalon $\mathrm{SiC}$ fiber $[1,2]$. These results were obtained using as-produced single fibers removed from multifilament tow [3,4]. Before being used in CMC, the multifilament tows will typically be coated to provide a compliant interface and to protect the $\mathrm{SiC}$ fiber against matrix reaction during composite fabrication and against oxidation during application. Currently a leading interfacial coating candidate is $\mathrm{BN}$ over-coated with $\mathrm{Si}_{3} \mathrm{~N}_{4}$ or $\mathrm{SiC}$.
\end{abstract}

Although the structural performance of CMC can be analyzed using single fiber data and various analytical theories, data obtained on multifilament tow should be more statistically accurate since the tow represents the average behavior of many fibers ( 500 to 800 ). Therefore, the objectives of this study were (1) to measure the time/temperature-dependent deformation and fracture behavior of uncoated and coated SiC fiber multifilament tows, and (2) to compare the multifilament behavior with single fiber data measured under the same conditions in order to evaluate the adequacy of limited single fiber data to model the behavior of multifilament fibers in a tow.

\section{Experimental Procedure}

Four types of $\mathrm{SiC}$ multifilament tows were studied: as-produced Dow Corning and Hi-Nicalon fibers from Dow Corning and Nippon Carbon, respectively; and $\mathrm{BN} / \mathrm{Si}_{3} \mathrm{~N}_{4}$ coated Dow Corning and Hi-Nicalon fibers. The $\mathrm{BN}$ interfacial coating and the $\mathrm{Si}_{3} \mathrm{~N}_{4}$ overcoating were produced by $\mathrm{CVD}$ by the $3 \mathrm{M}$ company with an average thickness for each layer of about $0.5 \mu \mathrm{m}$. The average diameters were 10 and $14 \mu \mathrm{m}$ for the single Dow Corning and Hi-Nicalon fibers, respectively. The number of fibers in each tow were counted to be $\mathrm{N} \sim 800$ and $\mathrm{N} \sim 500$ for the Dow Corning and Hi-Nicalon tows, respectively. The average cross-sectional areas for the Dow Corning and $\mathrm{Hi}$-Nicalon multifilament tows were assumed to be $\mathrm{N}$ times the average single fiber area based on the average diameter for each type. 
For each tow specimen, the fiber tow was aligned on paper tabs separated by a 125 or $225 \mathrm{~mm}$ grip to grip length. The tow was bonded to its tabs by epoxy resin which was squeezed under another paper tab, and then cured in a preheated oven at $90^{\circ} \mathrm{C}$ for 12 hours. The fugitive sizing on as-produced tows and the $\mathrm{BN} / \mathrm{Si}_{3} \mathrm{~N}_{4}$ coatings aided in avoiding slack in the individual fibers. Fig. 1 shows a typical cross section of paper-tabbed grip area, indicating that every fiber was embedded evenly in the epoxy resin with no significant fiber-fiber contact.

The SiC fiber tows were tensile tested to fracture from room temperature to $1400^{\circ} \mathrm{C}$ in air using a constant displacement rate of $1.27 \mathrm{~mm} / \mathrm{min}$. Warm-up rupture testing using deadweight loading and constant heating rate was also used to $1400^{\circ} \mathrm{C}$ in air and vacuum. Deadweight loading was employed for creep-rupture testing at 1200 and $1400{ }^{\circ} \mathrm{C}$ in argon for 0.1 to $\sim 100$ hours. The grip to grip lengths and hot zone lengths were respectively $\sim 125$ and $25 \mathrm{~mm}$ for the air tests, and $\sim 225$ and $100 \mathrm{~mm}$ for the argon and vacuum tests. The creep and rupture test facilities for the fiber tows were the same as used previously for single fibers $[3,4]$.

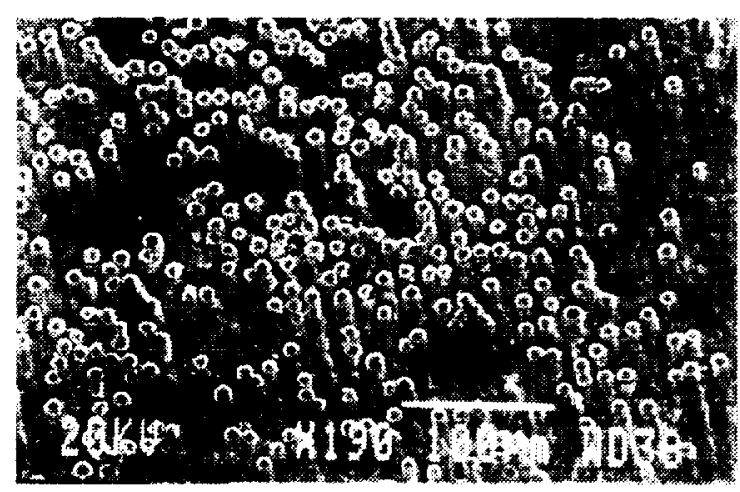

Fig.1 Typical cross section of the paper tabbed area during specimen preparation of $\mathrm{SiC}$ fiber tows.

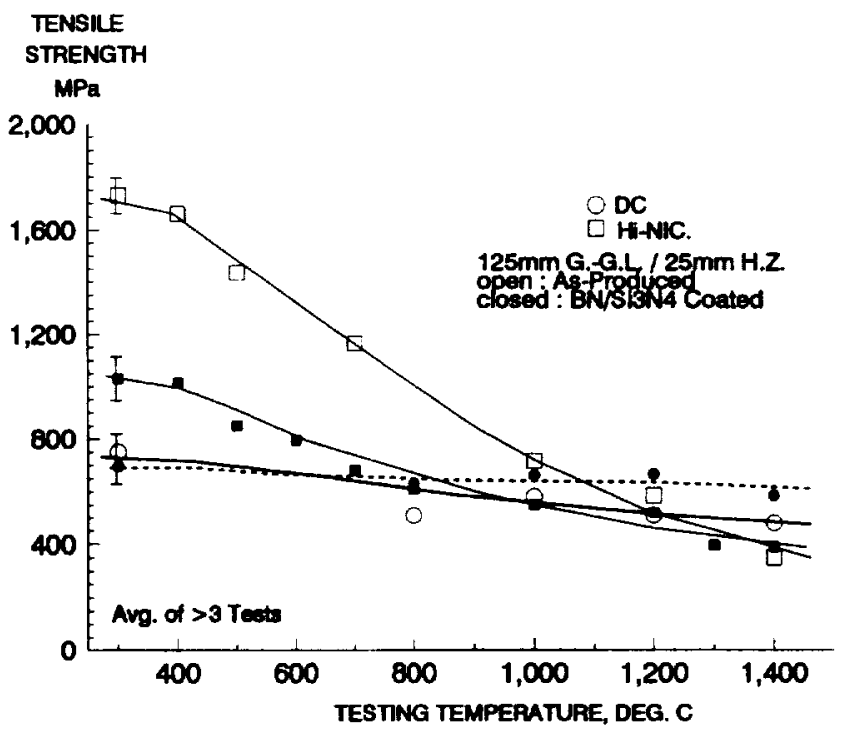

Fig. 2 Fast fracture strength of $\mathrm{SiC}$ multifilament tows measured at temperature in air.

\section{$\underline{\text { Results }}$}

\section{TENSILE STRENGTH:}

The fast fracture strengths measured at temperature in air are shown in Fig. 2 for the 4 different types of SiC tows. Each data point is the average of at least 3 specimens. The strengths were calculated by dividing the fracture load by the total area of the bundle, assuming that the coating or sizing did not carry any load. The room temperature strengths for coated and uncoated Dow Corning tows at $125 \mathrm{~mm}$ grip-to-grip length were nearly identical, $750 \mathrm{MPa}$; but the room temperature strength of the uncoated Hi-Nicalon fiber tow was much higher than that of the coated Hi-Nicalon tows. The large difference in strength is not fully understood, but may be due to a possible strength drop during CVD coating. 
The large strength drop beginning near $\sim 400 \mathrm{C}$ for the Hi-Nicalon tows suggests that the individual HiNicalon fibers were affected by oxygen in the air environment. One possible mechanism is $\mathrm{SiO}_{2}$ formation on the fiber surface, causing partial fiber-fiber bonding and early tow failure when the first fiber fails. Another possible strength degradation mechanism is oxygen attack of the free carbon in the stressed Hi-Nicalon fibers. This mechanism is supported by the absence of significant temperature-dependent strength loss in the stoichiometric Dow Corning fiber.

In confirmation of the oxygen attack issue, Fig. 3 shows warm-up rupture strengths of Hi-Nicalon tows measured in air and vacuum at a warm-up rate $10^{\circ} \mathrm{C} / \mathrm{min}$. At a same stress, like $1200 \mathrm{MPa}$, the uncoated $\mathrm{Hi}$-Nicalon tow ruptured in air at $\sim 600^{\circ} \mathrm{C}$; whereas in vacuum ruptured at $\sim 1200^{\circ} \mathrm{C}$. Furthermore, the strength of the coated $\mathrm{Hi}$-Nicalon tow remained the same up to $1200^{\circ} \mathrm{C}$ in vacuum, indicating that in the intermediate temperature range the fast fracture strengths of coated $\mathrm{Hi}$-Nicalon fiber tow were also airsensitive.

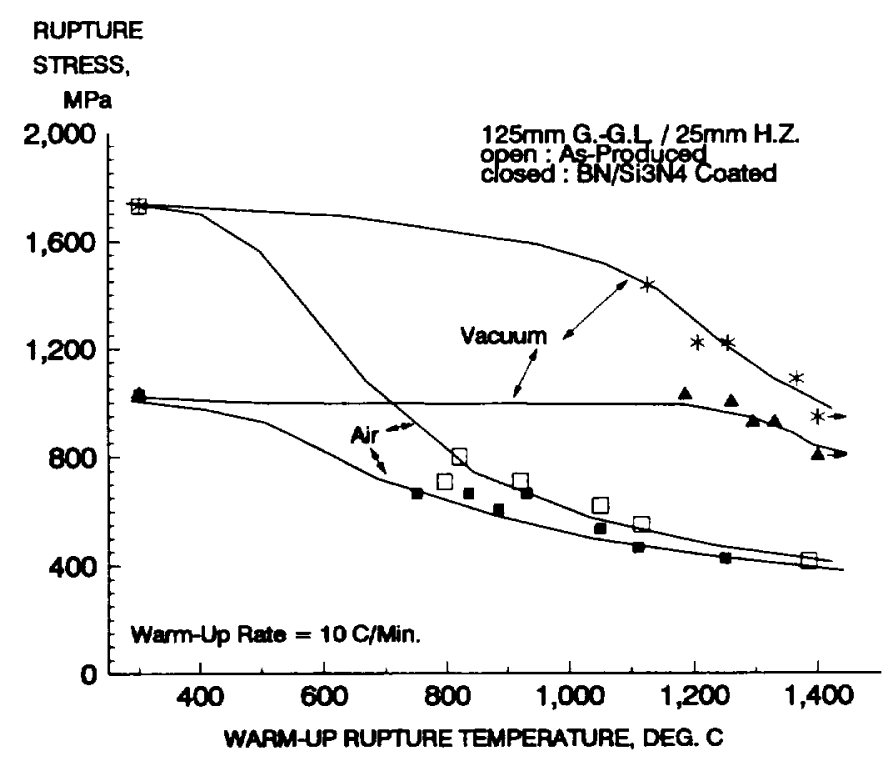

Fig.3 Warm-up rupture strengths of uncoated and coated Hi-Nicalon multifilament tows in air and vacuum.

\section{CREEP BEHAVIOR:}

Typical creep curves for the SiC fiber tows are shown in Fig. 4 as measured in argon at $1400^{\circ} \mathrm{C}$ and $300 \mathrm{MPa}$. Also shown is a creep curve for an as-produced single $\mathrm{Hi}$-Nicalon fiber. Most curves displayed a large transient creep stage. As with single fibers $(3,4)$, the transient creep behavior was more severe for the Hi-Nicalon tows than the Dow Corning tows. In Fig. 4, the creep failure strain of the Hi-Nicalon tow was over 1\%, while that of the Dow Corning tow was less than $1 \%$. In general, the tow creep results were similar to average single fiber behavior, but the coated fibers displayed lower creep stain than the uncoated as-produced fibers. At low creep strain the tows generally crept slightly more than single fibers; while at higher creep strains, the single fibers crept slightly more than the tows, but typically ruptured much earlier than the tows. 


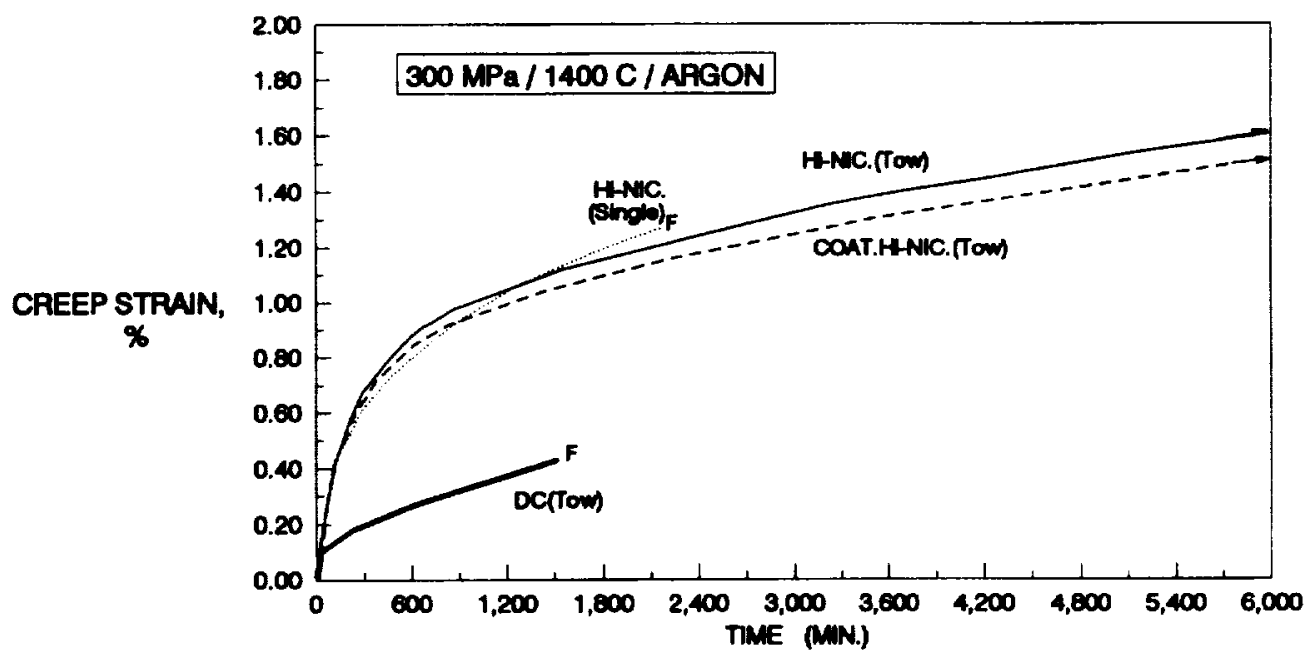

Fig.4 Typical creep curves of SiC fibers and multifilament tows at $1400^{\circ} \mathrm{C}$.
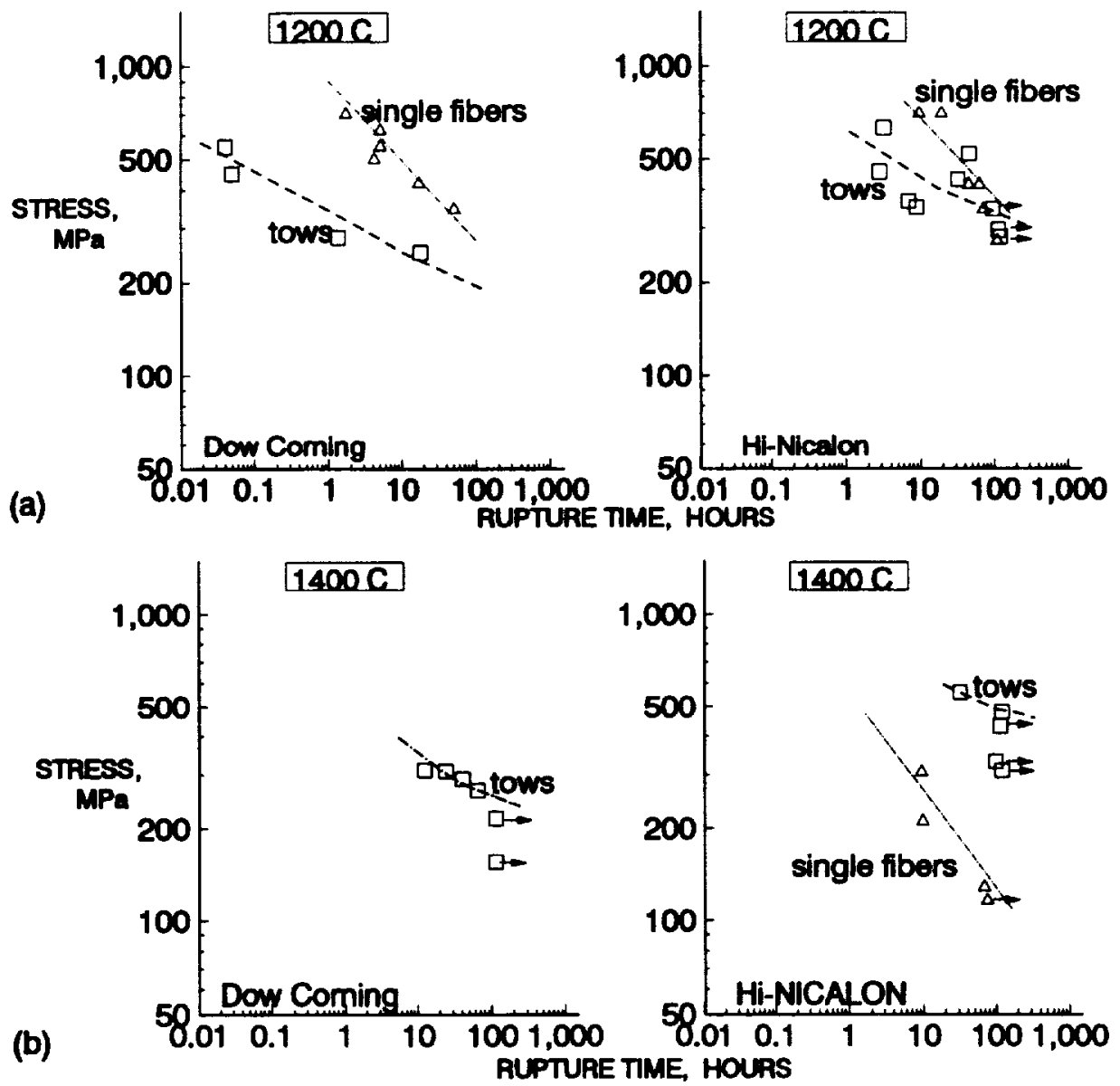

Fig.5 Stress-rupture strengths of uncoated single fibers and multifilament tows at (a) 1200 and (b) $1400^{\circ} \mathrm{C}$. 


\section{RUPTURE STRENGTH:}

Plots of applied stress versus rupture time are shown in Fig. 5 at (a) 1200 and (b) $1400^{\circ} \mathrm{C}$ for uncoated tows and single fibers tested in argon. The time dependency of the rupture strengths for the fiber tows was much weaker at 1200 and $1400^{\circ} \mathrm{C}$ than that of the single fibers. At $1200^{\circ} \mathrm{C}$, the fiber tows displayed lower shorttime rupture strengths than the single fibers. Long-time rupture strengths of the fiber tows at $1200^{\circ} \mathrm{C}$ were observed to be nearer those of the single fibers. This trend was more evident at $1400^{\circ} \mathrm{C}$, where the rupture strengths of the fiber tows were higher than the single fibers for both short-time and long-time conditions. The time dependency of the rupture strengths for the single fibers increased with increasing temperature; whereas that of the fiber tows appeared not to decrease with increase in temperature from 1200 to $1400^{\circ} \mathrm{C}$.

Plots of applied stress versus rupture time of the $\mathrm{BN} / \mathrm{Si}_{3} \mathrm{~N}_{4}$-coated fiber tows are shown in Fig. 6. The coated Dow Corning and $\mathrm{Hi}$-Nicalon tows were observed to have rupture strengths similar to those of the uncoated fiber tows.

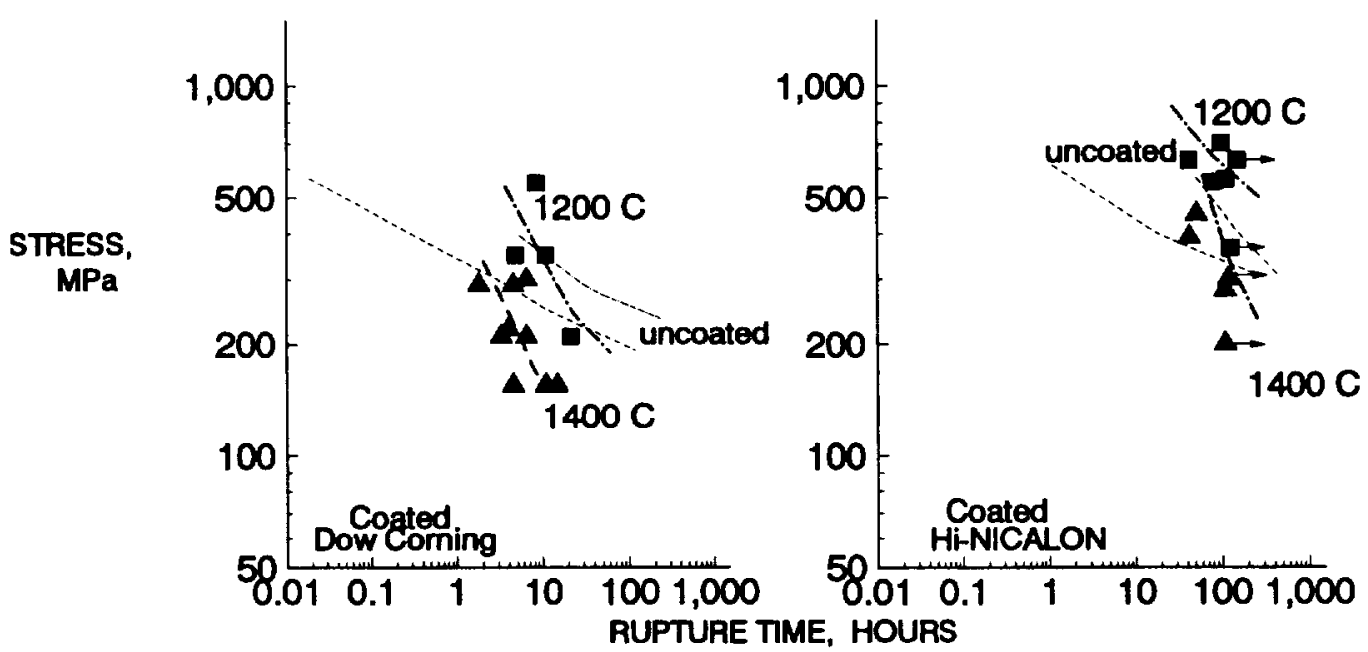

Fig.6 Stress-rupture strengths of $\mathrm{BN} / \mathrm{Si}_{3} \mathrm{~N}_{4}$-coated Hi-Nicalon and Dow Corning tows.

\section{Discussion}

\section{TENSILE STRENGTH:}

The fast fracture strengths for the Dow Corning and Hi-Nicalon fiber multifilament tows were observed to be lower than those for the average single fibers. This behavior is anticipated based on Weibull bundle theory $[5,6]$. To apply this theory, it is assumed that fiber fracture can be described by 2-parameter Weibull theory and that all individual fibers were equally loaded. Although not addressed here, the issue of unequal stresses during tow testing could be caused by (1) initial slack in individual fibers during tow specimen preparation and/or (2) variable elastic and creep compliances in individual fibers. These factors may result in high stress loading of less than the initial number of filaments and tow fracture loads less than equally loaded fibers.

Under the same gauge length conditions for single and tow fibers, the ratio $\mathrm{R}$ of tow fiber strength to average single fiber strength is given by Weibull theory as,

$$
\mathrm{R}=(1 /(\mathrm{me}))^{(1 / \mathrm{m})} / \Gamma((\mathrm{m}+1) / \mathrm{m})
$$


where $\mathrm{m}$ is Weibull modulus, $\mathrm{e}$ is the base of natural logarithm, and $\Gamma$ is Gamma function [5]. Using the warm-up data in vacuum (Fig. 3) for the Hi-Nicalon fiber ( $100 \mathrm{~mm}$ hot zone) and the fast-fracture data in air (Fig. 2) for the Dow Corning fibers ( $25 \mathrm{~mm}$ hot zone), measured $\mathrm{R}$ values for the two fiber types are shown in Fig. 7 as a function of testing temperature. The left hand side of the $y$-axis is the ratio $R$, and the right hand side of the $y$-axis is the corresponding Weibull modulus by Eq. (1). The average single fiber strengths measured at the same hot zone lengths were taken from the references $[4,7,8]$. From Fig. 8, it is seen that the $R$ values for both fiber tows are effectively temperature-independent, suggesting $m \sim 2$ for Dow Corning and $\mathrm{m} \sim 6$ for Hi-Nicalon across a wide temperature range and fast-fracture conditions. These values compare favorably with $\mathrm{m}$ values derived from $25 \mathrm{~mm}$ single fiber strength data at room temperature; that is $\mathrm{m} \sim 6$ for Dow Corning and $\mathrm{m} \sim 4$ for Hi-Nicalon. The close agreement suggests that if unequal stresses exist in the tows, they do not appreciably affect fast fracture data.

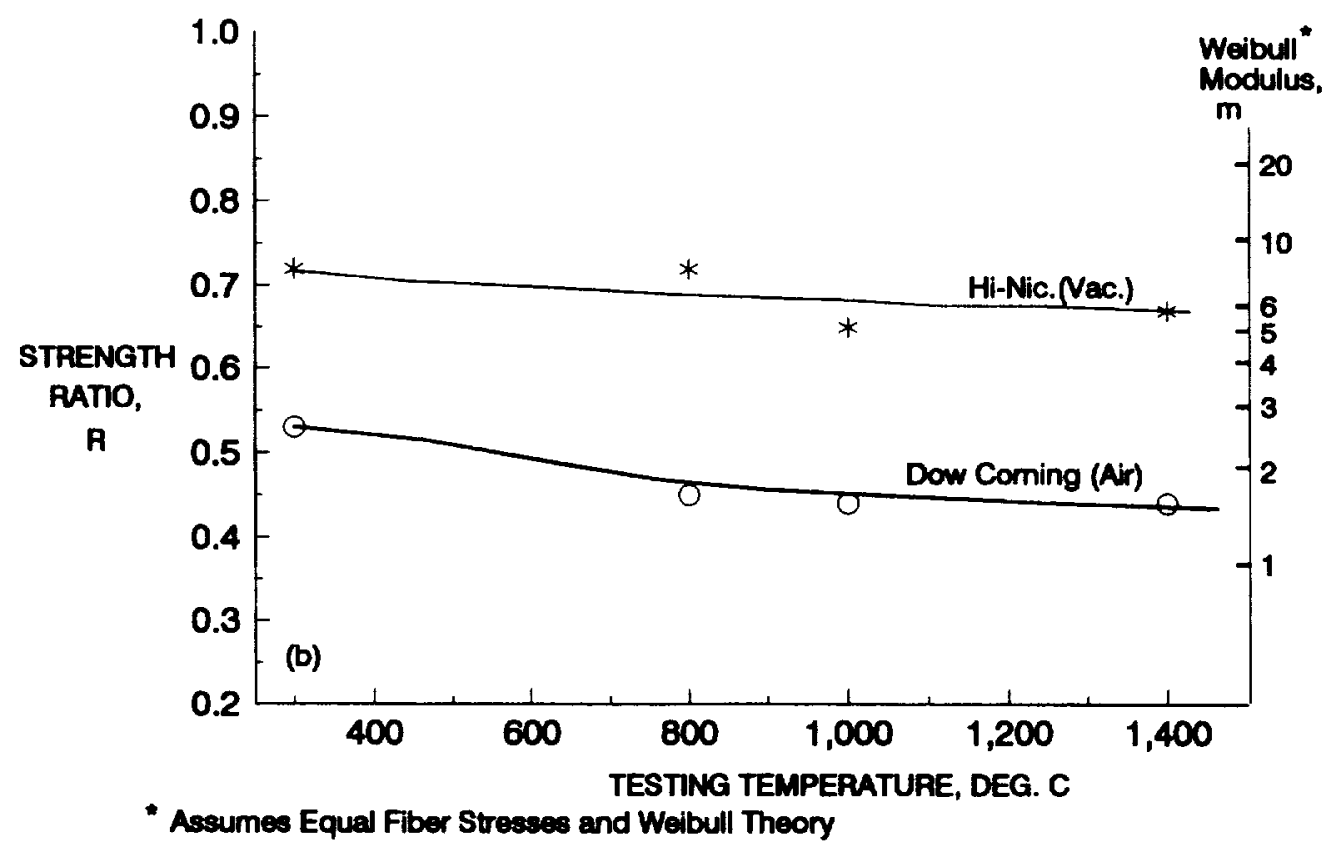

Fig.7 Evaluation of the temperature-dependencies of the $\mathrm{SiC}$ fiber Weibull moduli by the ratio $\mathrm{R}$ of tow to single fiber strength.

\section{RUPTURE STRENGTH:}

The fact that the high-temperature long-time rupture strengths for the Dow Corning and Hi-Nicalon fiber tows were larger than the average rupture strengths of single fibers can not explained by the simple Weibull bundle theory; that is, $\mathrm{R}$ cannot be greater than unity. The source of this unexpected observation is still uncertain, but may be due to variable creep compliances for the fibers in the tow. For equal loading and constant total applied load, variable creep compliances in individual fibers may cause load transfer from fiber to fiber as it often happens in composite systems where the load is transferred from the creep-prone matrices to the creepresistant fibers. For the tow, the more creep-prone individual fibers may relax their load and allow the less creep-prone fibers to carry more load. This load or stress transfer to the more creep-resistant and probably stronger fibers may reduce net creep of the tows and improve rupture life over average single fibers. The magnitude of these effects may be dependent on such factors as the mechanisms for SiC fiber transient behavior, the creep stress exponent, and the length of tow outside of the hot zone. Further experiments will be conducted to examine these factors in a systematic manner. 


\section{$\underline{\text { Summary }}$}

Fast fracture strengths, rupture strengths, and creep behavior of as-produced and $\mathrm{BN} / \mathrm{Si}_{3} \mathrm{~N}_{4}$-coated Dow Corning and Hi-Nicalon multifilament tows were measured from 20 to $1400^{\circ} \mathrm{C}$ in air and inert environments. Fast fracture results in air and vacuum indicated that the Hi-Nicalon tow strengths in air were reduced by oxygen-attack effects above $400^{\circ} \mathrm{C}$. The ratio of tow to single fiber strength measured in inert conditions for short-time fracture and rupture indicated that multiple fiber strengths can be predicted by using single fiber strength data and Weibull bundle theory with Weibull moduli of $\sim 2$ and $\sim 6$ for the Dow Corning and Hi-Nicalon fibers, respectively. Under conditions of high fiber creep, load transfer between fibers during tow creep testing apparently results in greater tow rupture strengths when compared to average single fiber strength behavior.

\section{$\underline{\text { References }}$}

(1) J.A. DiCarlo and S. Dutta: Continuous Ceramic Fibers for Ceramic Composites. HANDBOOK ON CONTINUOUS FIBER REINFORCED CERAMIC MATRIX COMPOSITES, eds. R.Lehman, S.El-Rahaiby, and J.Wachtman, Jr., Ceramic Information Analysis Center, Purdue University, West Lafayette, Indiana, 1995.

(2) M. Takeda, J. Sakamoto, Y. Imai, H. Ichkawa, and T. Ishkawa: Properties of Stoichiometric Silicon Carbide Fiber Derived from Polycarbosilane, Ceramic Eng. Sci. Proc., 15, 1994, pp.133-141.

(3) H.M. Yun, J.C. Goldsby, and J.A. DiCarlo, "Tensile Creep and Stress-Rupture Behavior of Polymer Derived SiC Fibers", NASA TM 106692, 1994.

(4) H.M. Yun, J.C. Goldsby, and J.A. DiCarlo, "Environmental Effects on Creep and Stress-Rupture Properties of Advanced SiC Fibers", Proc. 2nd International Conf. on High Temperature CMC, Santabarbara, CA, Aug., 1995, eds. A.G.Evans and R.Naslain, The American Ceramic Soc., 1995, pp. 331-336.

(5) B.W. Rosen, "Thermomechanical Properties of Fibrous Composites", Proc. Roy. Soc. Lond. A. 319, 1970, pp. 79-94.

(6) W. Weibull, “A Statistical Distribution Function of Wide Applicability”, J. Appl. Mech., 18, 1951, pp. 293-296.

(7) R. Bodet, X. Bourrat, J. Lamon, and R. Naslain, "Tensile Creep Behavior of a Silicon Carbide-Based Fiber with a Low Oxygen Content", PhD Thesis, Domaine Universitaire, France, 1994.

(8) J.B. Hurst, H.M. Yun, D. Gorican, and J.A. DiCarlo, "Creep and Stress-Rupture Behavior of Sintered SiC Fibers", presented at 1994 Annual Cocoa Beach Conf. on Composites, American Ceramic Society, Cocoa Beach, FL, 1994. 
Public reporting burden for this collection of information is estimated to average 1 hour per response, including the time for reviewing instructions, searching existing data sources, gathering and maintaining the data needed, and completing and reviewing the collection of information. Send comments regarding this burden estimate or any other aspect of this collection of information, including suggestions for reducing this burden, to Washington Headquarters Services, Directorate for Information Operations and Reports, 1215 Jefferson Davis Highway, Suite 1204, Arlington. VA 22202-4302, and to the Office of Management and Budget. Paperwork Reduction Project (0704-0188), Washington, DC 20503.

\begin{tabular}{|l|l|l}
\hline 1. AGENCY USE ONLY (Leave blank) & $\begin{array}{c}\text { 2. REPORT DATE } \\
\text { January } 1997\end{array}$ & $\begin{array}{r}\text { 3. REPOAT TYPE AND DATES COVERED } \\
\text { Technical Memorandum }\end{array}$
\end{tabular}

4. TITLE AND SUBTITLE

Thermomechanical Behavior of Advanced SiC Fiber Multifilament Tows

6. AUTHOR(S)

Hee Mann Yun and James A. DiCarlo

7. PERFORMING ORGANIZATION NAME(S) AND ADDRESS(ES)

National Aeronautics and Space Administration

Lewis Research Center

Cleveland, Ohio 44135-3191

9. SPONSORINGMONITORING AGENCY NAME(S) AND ADDRESS(ES)

National Aeronautics and Space Administration

Washington, DC 20546-0001
5. FUNDING NUMBERS

WU-537-04-20

8. PERforming organzation REPORT NUMBER

E-10528

10. SPONSORINGMONITORING AGENCY REPORT NUMBER

NASA TM- 107366

11. SUPPLEMENTARY NOTES

Prepared for the 20th Annual Conference on Composites, Advanced Ceramics, Materials, and Structures sponsored by the American Ceramic Society, Cocoa Beach, Florida, January 7-11, 1996. Responsible person, Hee Mann Yun, organization code 5120 , (216) 433-6089.

\begin{tabular}{|l|l|} 
12a. DISTRIBUTIONAVALABILTTY STATEMENT & 12b. DISTRIBUTION CODE
\end{tabular}

Unclassified - Unlimited

Subject Category 24

This publication is available from the NASA Center for AeroSpace Information, (301) $621-0390$.

13. ABSTRACT (Maximum 200 words)

In order to relate single fiber behavior to multiple fiber behavior in composites, fast-fracture tensile strength, creep, and stress-rupture studies were conducted on advanced $\mathrm{SiC}$ fiber multifilament tows in the temperature range from 20 to 1400 $\mathrm{C}$ in air as well as in inert environments. For conditions of small fiber creep (short times and low temperatures), the tow results of this study confirm the ability of limited single fiber data to model the strength behavior of multiple fibers in a bundle. For conditions of high creep (long times and high temperatures), further studies are needed to explain tow rupture behavior being better than average single fiber behavior.

14. SUBJECT TERMS

Hi-Nicalon; Dow-Corning; SiC fiber; Creep; Stress-rupture; Multifilament; Bundle; Composites

15. NUMBER OF PAGES

10

16. PRICE CODE

$\mathrm{A} 02$

17. SECUATTY CLASSIFICATION OF REPOAT

Unclassified
18. SECURTYY CLASSIFICATION OF THIS PAGE

Unclassified
19. SECURITY CLASSIFICATION OF ABSTRACT Unclassified 